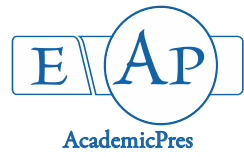

\title{
Diversity and Distribution of Endomycorrhizae and Dark Septate Endophytes of some Economically Important Bamboos of Assam, India
}

\author{
Vipin PARKASH ${ }^{1 *}$, Liza HANDIQUE ${ }^{2}$, Priya DHUNGANA ${ }^{2}$ \\ ${ }^{1}$ Forest Research Institute (ICFRE), Forest Protection Division, Dehradun 248006, Uttarakhand, \\ India; bhardwajupnark@rediffmail.com (*corresponding author) \\ ${ }^{2}$ Rain Forest Research Institute, Jorhat 785001, Assam, India; lizahandique@rediffmail.com; dhunganapriya@rediffmail.com
}

\begin{abstract}
The genus Bambusa Schreb. which belongs to the Poaceae family is commonly present in north-eastern region of India. A survey was undertaken in three villages viz. Tilikiaam, Maoutgaon and Nathgaon of Jorhat district, Assam, North-east India, where natural populations of Bambusa species were observed. Four bamboo species i.e. Bambusa bambos (L.) Voss, B. tulda Roxb., B. pallida Munro and B. nutans Wall. ex. Munro were found locally economically important and the rhizospheric soil and root samples were collected for screening of dark septate endophytes (DSE) as well as arbuscular mycorrhizal (AM) colonization. Quantitative analysis of root samples showed the presences of all the three types of endomycorrhizal root infection/colonization namely hyphal, vesicular and arbuscular. Beside this, the dark septate endophytic infections were also observed in all the bamboo species. The cent-percent endomycorrhizal (hyphal and vesicular) and DSE hyphal infections were reported in roots of all the bamboo species respectively. There were variations observed in arbuscular infection in B. nutans and B. bambos (100\%), B. pallida (90\%) and least in B. tulda (70\%). Qualitative analysis revealed that the Endomycorrhizae found in the rhizospheric soil predominantly belongs to five genera viz. Glomus, Acaulospora, Gigaspora, Scutellospora and Entrophospora. The genus Glomus, is the most dominant, with 17 species (61\%), Acaulospora with 7 species (25\%), Entrophospora with 2 species (7\%), Scutellospora (3.5\%) and Gigaspora (3.5\%) with 1 species each. Distribution of AM fungi were highest in B. bamboos (67.7\%) followed by B. pallida (19.4\%), B. tulda (11.1\%) and least in B. nutans (2.8\%). Bamboo resources have been considerably declining due to exploitation, shifting cultivation, gregarious flowering and extensive forest fires from the natural habitats. Therefore, further microbial based applied researches should be undertaken to protect the dwindling natural bamboo resources and considering AMF bioinoculants in future management practices in order to maintain diminishing ecosystems.
\end{abstract}

Keywords: bambusicolous fungi; endophytic fungi; rhizosphere; root colonization; VAM fungi

\section{Introduction}

In addition to being susceptible to soil-borne pathogens, plant roots are also colonised by non-pathogenic or mutualistic fungi like arbuscular mycorrhizae (AM), ectomycorrhizae (EM) and dark septate endophytes (DSE). The majority (probably $70-80 \%$ ) of terrestrial plants are capable of interacting with arbuscular mycorrhizal (AM) fungi in nature (Jiang et al., 2013). Mycorrhizas form a symbiotic association with the roots of host plants, where carbon flows to the fungus and inorganic nutrients move to plant. These fungi develop external hyphae approximately 3 $\mathrm{m}$ in diameter (Simard et al., 2002). The hyphae produce arbuscules and in most fungal genera, vesicles act as a bridge connecting the root with the surrounding soil (Allen, 1992). The AM fungi are characterized by the formation of an extraradical mycelium and branched haustorial structures within the cortical cells, termed arbuscules (Hock and Varma, 1995). The symbiotic nature of VAM fungi with higher plants plays an important role in plant nutrition cycle (Harley and Smith, 1983). In recent years, it has been well established that the VAM (Vesicular Arbuscular Mycorrhizal) fungi influence plant growth and biomass production (Hall, 1988). This is brought out by alterations in host physiology. Like photosynthesis, root exudation, carbohydrate and the amino acid status (Nemec and Meredith, 1981; Nemec and Guy, 1982; Harries et al., 1985). They may be involved in improving uptake of macro- and micronutrient, increasing plant resistance against biotic and abiotic stress, and beneficial alternations of plant growth regulators (Smith, 1996; Liu and Li, 2000; Govindarajulu et al., 2005; Cruz and Husain, 2008; Smith and Read, 2008). Nowadays, mycorrhizal fungi have been 
448

widely used in agriculture, horticulture, and forestry programs, as well as for environmental reclamation, to increase crop yield and health and to limit the application of agrochemicals (Johansson et al., 2004).

Dark septate endophytes (DSE) comprise a miscellaneous group of root-inhabiting fungi. A recent review (Jumpponen and Trappe, 1998) defined DSE as conidial or sterile ascomycetous fungi that colonize living plant roots without causing apparent negative effects such as tissue disorganization. DSE have been reported to possess a range of enzymatic capabilities (Currah and Tsuneda, 1993; Fernando and Currah, 1995; Haselwandter and Read, 1980; Caldwell et al., 2000). Caldwell et al. (2000), for example, concluded that DSE are able to utilize some of the major organic detrital nutrient pools (Jumponnen, 2001). DSE are found worldwide and coexist often with different mycorrhizal fungi. They have been reported from 600 plant species including plants that have been considered nonmycorrhizal (Jumpponen and Trappe, 1998).

In India, bamboo encompasses about 8.96 million hectares of forest area and its present usage is to the tune of Rs. 2,043 crores. Bamboo, being an important forest turn out, plays a vital role in the rural financial system of our country. In order to meet the future demand of bamboo, its growth and yield has to be hastened from the nursery stage onwards. Inoculations of different bamboo species with biofertilizers including arbuscular mycorrhizal (AM) fungi have been shown to significantly increase the plant growth and yield under variable conditions (Jha et al., 2012).

The occurrence and distribution of AMF in the forestry species including bamboo and association of AMF and dependency of bamboo species on them have been reported (Khan and Uniyal, 1999). Dash et al. (2008) have reported higher growth and biomass production of $D$. strictus, Bambusa bambos (L.) Voss. and B. vulgaris Wendl. Ex Nees, after inoculation with an unidentified AM species. However so far, there are no DSE studies on bamboos. Moreover, till date, a very few reports are available on the endomycorrhizal diversity on the bamboos of North East India. Thus, the present study was undertaken to enumerate the endomycorrhizal diversity associated with some of the economically important bamboos of Assam in North East India viz. Bambusa bambos (L.) Voss, Bambusa tulda Roxb., Bambusa pallida Munro and Bambusa nutans Wall. ex. Munro (Table 1).

\section{Materials and Methods}

Soilsample collection

The plant species were collected from three sites viz. Tilikiaam, Maoutgaon and Nathgaon of Jorhat district, Assam in North East India (Fig. 1) $\left(26.75^{\circ} \mathrm{N}-94.22^{\circ} \mathrm{E}\right)$ and the morphology of the target species was studied on spot. Rhizospheric soil samples (at least three samples) were taken by digging out a small amount of soil ( $500 \mathrm{~g}$ ) close to plant roots up to the depth of $15-30 \mathrm{~cm}$ and these samples were kept in sterilized polythene bags at $10{ }^{\circ} \mathrm{C}$ for further processing in the laboratory for analyses of endomycorrhizal micro-symbiotic associations.

\section{Isolation of $A M$ spores}

Isolation of AM spores was done by wet sieving and decanting technique (Gerdemann and Nicolson, 1963). Approximately $100 \mathrm{~g}$ of soil was suspended in 1 litre or more of water. Heavier particles were allowed to settle for a few seconds to overnight and the liquid was decanted through sieves of different sizes in the order $150 \mu \mathrm{m}, 120$ $\mu \mathrm{m}, 90 \mu \mathrm{m}, 63 \mu \mathrm{m}, 45 \mu \mathrm{m}$ and $20 \mu \mathrm{m}$ which removes large particles of organic matter, but course enough to allow the desired spores to pass through. The sieving retained on different sieves was collected on different Petri dishes then the trapped spores were transferred to Whatman filter paper no. 1 by repeating washing with water. The spores were picked by hypodermic needle under stereo- binocular microscope.

\section{Mycorrhizal quantification}

For quantitative estimation of AM spores, Gaur and Adholeya (1994) modified method was used. The filter paper was divided into many small sectors by marking with a ball pen. The total number of spores was counted by adding the number of spores present in each sector under stereo-binocular microscope.

\section{Identification of $V A M \approx A M$ fungi}

For identification of AM spores the following criteria were used like conventional morphological character i.e. colour, size, shape wall structure, surface, ornamentation of spores, nature and size of subtending hyphae, bulbous suspensor, the number and arrangement of the spores in the sporocarp. These AM spores were identified by using the keys of Schenckand Perez (1990), Morton and Benny (1990) and Mukerji (1996).

\section{Clearing and staining of root segments}

Rhizospheric root samples were stained according to Phillips and Hayman (1970) method. Roots were first cleared with $10 \%(\mathrm{w} / \mathrm{v}) \mathrm{KOH}$ at $98^{\circ} \mathrm{C}$ for one hour. After clearing, roots were bleached with a $5 \% \mathrm{H}_{2} \mathrm{O}_{2}(\mathrm{v} / \mathrm{v})$ solution for 10 minutes. All samples were acidified with $1 \%(\mathrm{v} / \mathrm{v})$ $\mathrm{HCl}$ for 5 minutes and stained with $0.05 \%$ (w/v) Trypan Blue in acidic glycerol by heating them at $98{ }^{\circ} \mathrm{C}$ for 15 minutes. The stained roots were stored in acidic glycerol for further study.

Table 1. Selected bamboo species along with their local name and economic uses in Assam

\begin{tabular}{|c|c|c|}
\hline Botanical names & Local name & Importance \\
\hline Bambusa bambos (L.) Voss & Kotoha & $\begin{array}{l}\text { Live hedge, paper and pulp, scaffolding and construction, rafts, shoots and seed are } \\
\text { edible }\end{array}$ \\
\hline Bambusa tulda Roxb. & Jati & Construction, scaffolding, basketry, handicraft and woven application \\
\hline Bambusa pallida Munro & Bijuli & Basket making and mats and artefacts \\
\hline Bambusa nutans Wall. ex. Munro & Mokal & Construction, scaffolding, basketry and handicraft, artisans \\
\hline
\end{tabular}




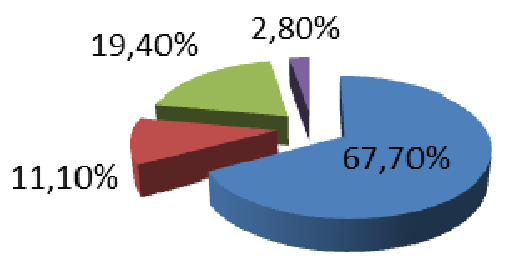

Fig. 1. Pie chart showing the distribution of AM fungi

\section{Analyses of the root samples}

Ten stained root pieces approximately $1 \mathrm{~cm}$ long were mounted on a slide in glycerol and were examined with a light trinocular microscope (Labovision, BIOXL). A total of three replicates were made. Typical structures that indicated the presence of mycorrhizas or other root associated fungi were documented and micro-photographed with light trinocular microscope attached digital camera (Canon make A3100IS) and Image-Zoom Browser Ex analysis software for Windows 2008. The mycorrhizal type present in each sample was designated according to Harley and Smith (1983) classification. The criteria used in this study for the determination of AM was the presence of vesicles, arbuscules and mycelium at least in one individual root segment and the occurrence of the rest of typical AM structures in the samples (intra or intercellular hyphae, vesicles, coils and arbuscules). The intensity of length colonized by AM fungi was estimated according to the following formula.

Intensity of length colonized $\%=$ (total length of mycorrhizal infection/total length of root segment) $\times 100$

\section{Results and Discussion}

The rhizospheric soil sample of four species of Bambusa i.e. B. bambos, B. tulda, B. pallida and B. nutans was collected during November 2013 from three villages viz. Tilikiaam, Maoutgaon and Nathgaon of Jorhat district, Assam, where natural populations of Bambusa species were observed. The collected rhizospheric soil and root samples were screened for Dark Septate Endophytes (DSE) as well as Arbuscular mycorrhizal (AM) infection/colonization.

Quantitative analysis of root samples showed the presence of all the three types of endomycorrhizal root infection namely hyphal, vesicular and arbuscular. Beside this, the Dark Septate Endophytic infections were also observed in all the bamboo species. 100\% endomycorrhizal (hyphal and vesicular) and DSE hyphal infections were reported in roots of all the bamboo species. However, Das and Kayang (2010), reported the AMF infection were significantly higher than DSE colonization. In our study, variations were observed in arbuscular infection i.e. B. nutans (Plate 4) and B. bambos (100\%) (Plate 1), B. pallida (90\%) (Plate 3) and least in B. tulda (70\%) (see Plate 2 and Table 2). In studies conducted at the Department of Plant Pathology, Bidhan Chandra Krishi Viswavidyalaya, Kalyani, West Bengal, Dendrocalamus strictus showed above $40 \%$ VAM dependency for shoot dry matter production (Singh, 2001). Contradictorily, Jamalludin et al. (2001) noticed maximum root colonization of VAM in Bambusa nana followed by Bambusa vulgaris (green) out of all species of bamboos. The minimum root colonization was noticed in Bambusa bamboos (33.33\%). The root colonization percent was varied considerably among species to species. These variations in root colonization of bamboos species by VAM might be due to development of VAM in roots which are controlled by host nature and fungus root symbiosis (Gianinazzi Pearson et al., 1991) and Phosphorus acquisition of the host. Host reaction to penetration and proliferation of the fungus in roots is influenced by the presence of intracellular haustoria that the host cell develops the most specific modifications (Serrigny, 1982; BonfanteFasolo, 1984). The occurrence of heavy mycorrhizal infection could be attributed to nutrient stress and intense competition between surrounding plant species. The fibrous root systems of the early colonizing herbaceous species that occupied the site may also have contributed to the high level of infection, allowing better contact between the roots of different plant species and thus helping to spread the infection.

Table 2. Percentage infection and colonization of AM fungi

\begin{tabular}{|c|c|c|c|c|c|c|c|c|c|}
\hline \multirow{2}{*}{ Botanical name } & \multirow{2}{*}{ Accession No. } & \multicolumn{2}{|c|}{ Hyphal infection } & \multicolumn{2}{|c|}{ Vesicular infection } & \multicolumn{2}{|c|}{ Arbuscular infection } & \multirow{2}{*}{$\begin{array}{l}\text { Presence } \\
\text { of DSE* }\end{array}$} & \multirow{2}{*}{$\begin{array}{l}\text { AM Spore coun } \\
\quad(50 \mathrm{~g} \text { of soil })\end{array}$} \\
\hline & & $\begin{array}{c}\text { Colonization } \\
\%\end{array}$ & $\begin{array}{c}\text { Colonization } \\
\text { Intensity }\end{array}$ & $\begin{array}{c}\text { Colonization } \\
\%\end{array}$ & $\begin{array}{c}\text { Colonization } \\
\text { Intensity }\end{array}$ & $\begin{array}{c}\text { Colonization } \\
\%\end{array}$ & $\begin{array}{c}\text { Colonization } \\
\text { Intensity }\end{array}$ & & \\
\hline $\begin{array}{l}\text { B. bambos } \\
\text { (L.) Voss }\end{array}$ & JRT/AYUR/BB-01 & 100 & 50 & 100 & 68 & 100 & 44 & + & $104.7 \pm 8.45$ \\
\hline $\begin{array}{l}\text { B. tulda } \\
\text { Roxb. }\end{array}$ & JRT/AYUR/BT-02 & 100 & 30 & 100 & 78 & 70 & 70 & + & $110.0 \pm 4.56$ \\
\hline $\begin{array}{c}\text { B. pallida } \\
\text { Munro }\end{array}$ & JRT/MAG/BP-03 & 100 & 50 & 100 & 148 & 90 & 27 & + & $192.7 \pm 6.78$ \\
\hline $\begin{array}{l}\text { B. nutans } \\
\text { Wall. ex Munro }\end{array}$ & JRT/NAG/BN-04 & 100 & 50 & 100 & 85 & 100 & 100 & + & $52 \pm 8.42$ \\
\hline
\end{tabular}

${ }^{\text {*}}$ Dark Septate Endophytes, \pm SEm- Standard error of mean 
450

Other possible causes of a high level of mycorrhizal infection include dominance of the disturbed site by mycorrhizal weeds (Miller, 1979), plant age (Martin, 1971), and deficiencies of $\mathrm{N}$ and $\mathrm{P}$ in the soil (Hayman, 1975). According to Miller (1979), occurrence of vesiculararbuscular mycorrhizae (VAM) is controlled by the degree of disturbance and harshness of site. These could be another reason as reported by Miller (1979) explaining the abundance of mycorrhizal fungi in the study site. Jha et al. (1992) also explained the similar factor for disturbance of mycorrhizal fungi in degraded forest soil.

Qualitative analysis revealed that the endomycorrhizae found in the rhizospheric soil predominantly belongs to five genera viz. Glomus, Acaulospora, Gigaspora, Scutellospora and Entrophospora. Glomus with 17 species (61\%) is the most dominant genus followed by Acaulospora with 7 species (25\%), Entrophospora with 2 species (7\%) and least with 1 species (3.5\%) each of Scutellospora and Gigaspora respectively (Plate 5). Distribution of AM fungi were highest in $B$. bamboos (67.7\%) followed by $B$. pallida (19.4\%), B. tulda (11.1\%) and least in B. nutans (2.8\%) (Fig. $1)$.

About fifteen AM species, five belonging to genus Acaulospora (Acaulospora laevis, A. scrobiculata, A. lacunose, A. mellea, Acaulospora species) seven belonging to Glomus (Glomus clavisporum, G. reticulatum, G. macrocarpum, $G$. clariodeum, G. pansibalos, G. geosporum) two belonging to genus Gigaspora (Gigaspora gigantius, Gigaspora species) and one Entrophosphora species were recorded and isolated from the rhizosphere of naturally growing populations of $B$. bambos. Jha et al. (2012) reported eight AM inoculants ( $G$. aggregatum, G. arborense, G. cerebriforme, G. fasciculatum, G. hoi, G. intraradix, G. occultum and an unidentified Glomus species) significantly increased shoot length in $B$. bambos.

In Bambusa tulda, altogether four species belonging to three genera of AM were isolated viz. Acaulospora foveata, Glomus clavisporum, G. albidum and Scutellopora sp. Das and Kayang (2010) reported Bambusa tulda exhibited arum type of AMF morphology. In Bambusa pallida, altogether eight $\mathrm{AM}$ species were isolated out of which two belonging to Acaulospora (Acaulospora laevis, unidentified Acaulospora species) and rest of the six species belonging to genus Glomus were recorded viz. Glomus macrocarpum, $G$. monosporum, G. geosporum, G. epigaeum, G. fasciculatum and Glomus species. While only one species of AM fungi belonging to genus Glomus (G. epigaeum) were isolated from $B$. nutans. However, Jamaluddin et al. (2001) have reported significant increase in growth and biomass of $B$. nutans G. C. Wall. ex Munro after inoculation with AM inoculum obtained from rhizosphere of field grown plants of B. nutans, which contained G. mosseae, G. intraradix Schenck \& Smith and an unidentified species of Gigaspora.

Table 3. Occurrence of AM fungi among the bamboo species

\begin{tabular}{|c|c|c|c|c|c|}
\hline Sl. no. & Strains of AM fungi & B. bambos & B. tulda & B. pallida & B. nutans \\
\hline 1 & Acaulospora laevis Gerd.\& Trappe & + & - & + & - \\
\hline 2 & A. scrobiculata Trappe & + & - & - & - \\
\hline 3 & A. lacunose Morton & + & - & - & - \\
\hline 4 & A. mellea Spain and Schenck & + & - & - & - \\
\hline 5 & A. foveata Trappe \& Janos & - & + & - & - \\
\hline 6 & Acaulospora sp. & + & - & + & - \\
\hline 7 & Glomus clavisporum Almeida \& Schenck & + & + & - & - \\
\hline 8 & G. reticulatum Bhattacharjee \& Mukerji & + & - & - & - \\
\hline 9 & G. macrocarpum Tul. \& C. Tul & + & - & + & - \\
\hline 10 & G. monosporum Gerd. \& Trappe & - & - & + & - \\
\hline 11 & G. clariodeum Schenck \& Smith & + & - & - & - \\
\hline 12 & G. pansibalos Berch \& Koske & + & - & - & - \\
\hline 13 & G. albidum Walker \& Rhodes & - & + & - & - \\
\hline 14 & G. geosporum Nicolson \& Gerd. & + & - & + & - \\
\hline 15 & G. epigaeum Daniels \& Trappe & - & - & + & + \\
\hline 16 & G. fasciculatum Gerd. \& Trappe & - & - & + & - \\
\hline 17 & Glomus sp. & + & - & + & - \\
\hline 18 & Gigaspora gigantean Gerd. \& Trappe & + & - & - & - \\
\hline 19 & Gigaspora sp. & + & - & - & - \\
\hline 20 & Entrophospora sp. & + & - & - & - \\
\hline 21 & Scutellospora sp. & - & + & - & - \\
\hline
\end{tabular}



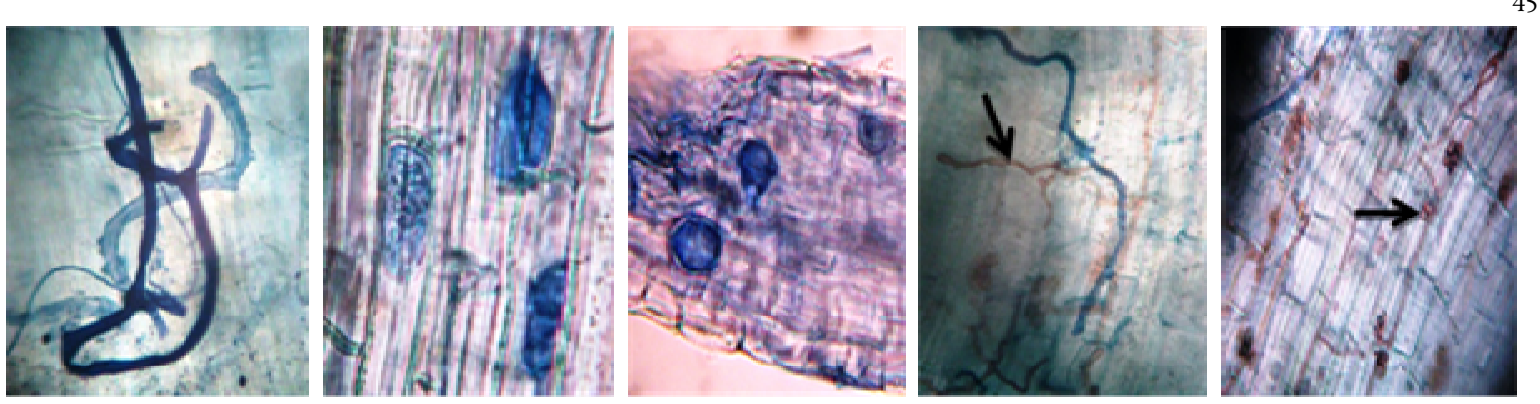

Plate 1. Hyphal, vesicular, arbuscular infection and DSE colonization in B. bambos
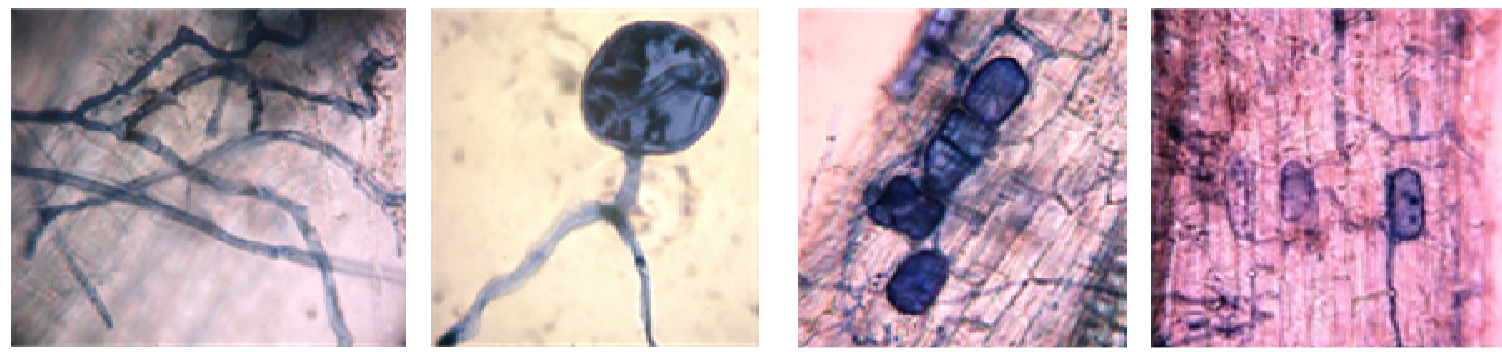

Plate 2. Hyphal, vesicular, arbuscular infection in B. tulda
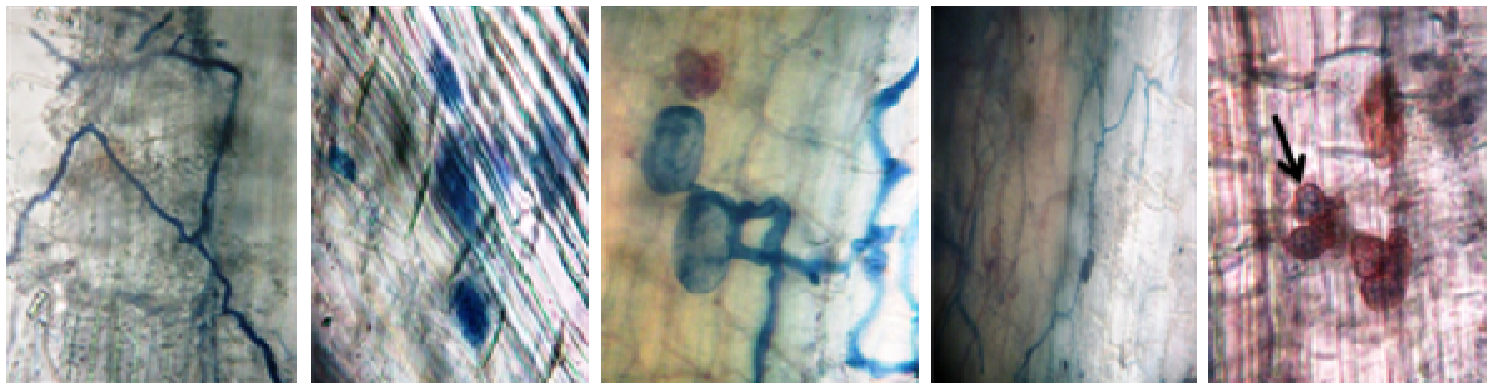

Plate 3. Hyphal, vesicular, arbuscular infection and DSE colonization in B. pallida
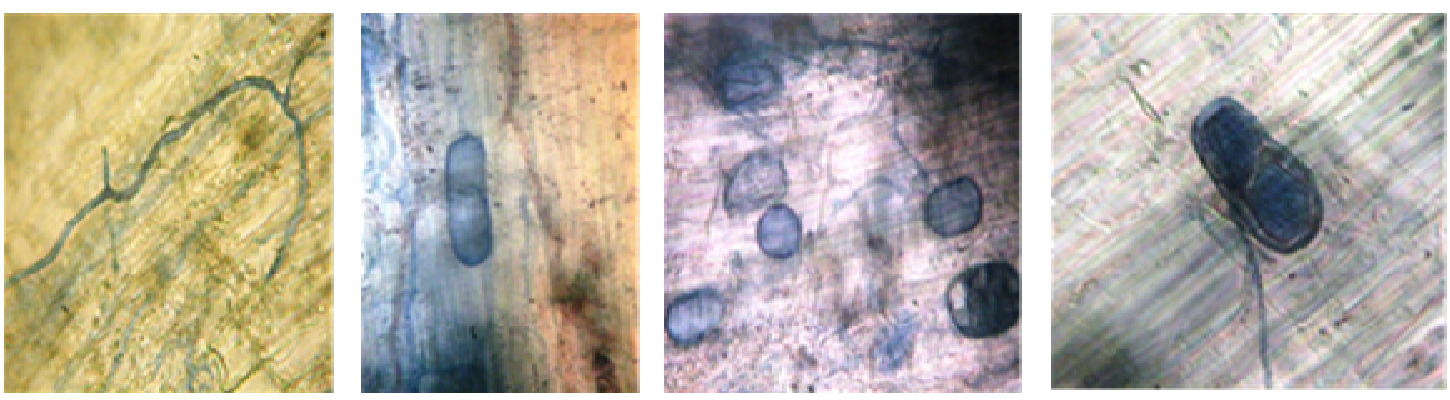

Plate 4. Hyphal, vesicular, arbuscular infection in B. nutans 

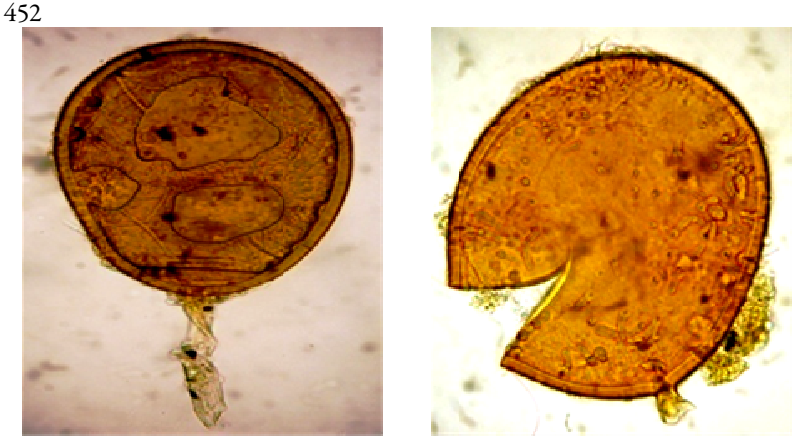

Glomus geosporum
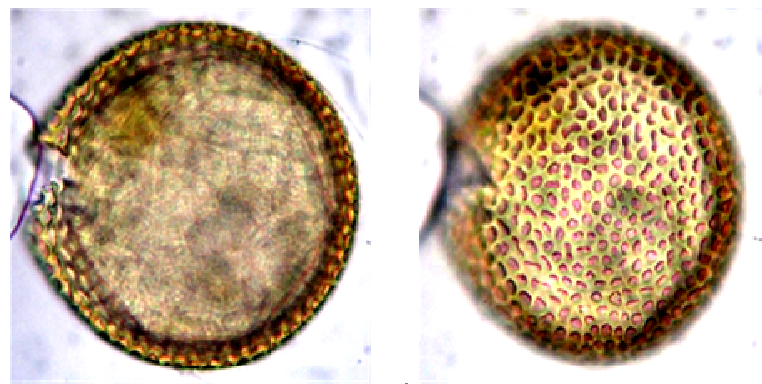

Acoulospora foveata

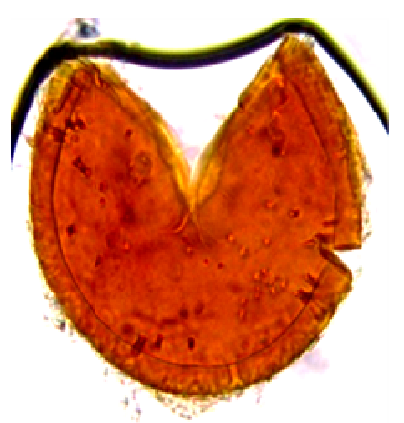

Glomus sp.

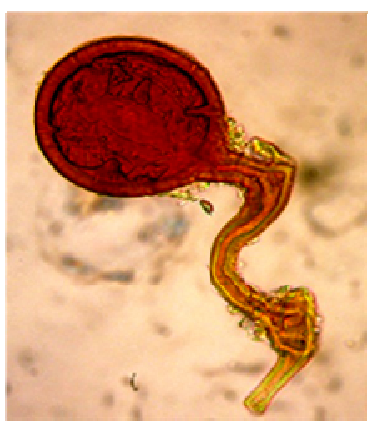

G. fasciculatum

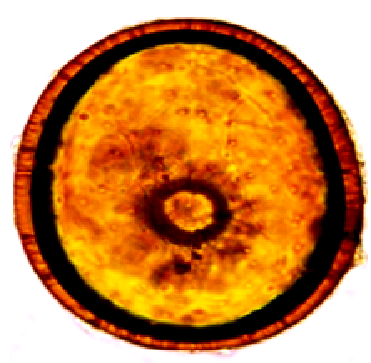

A.lacunoso

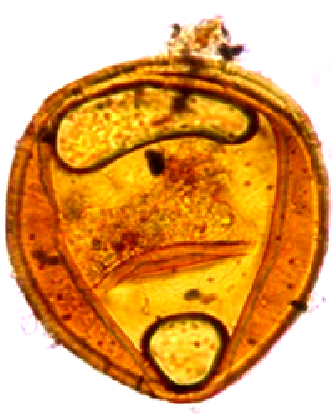

Gigasporagigantea
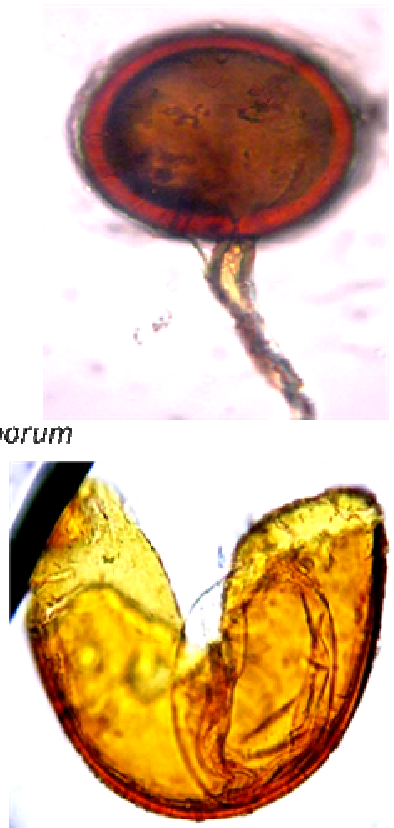

Scutellosporasp.

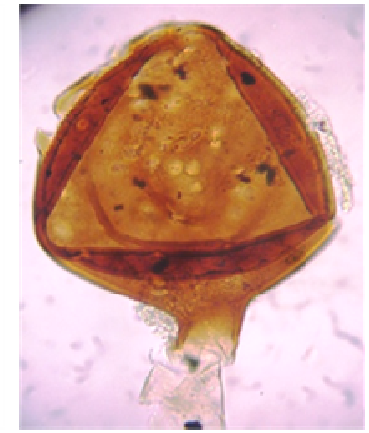

Gigasporosp.
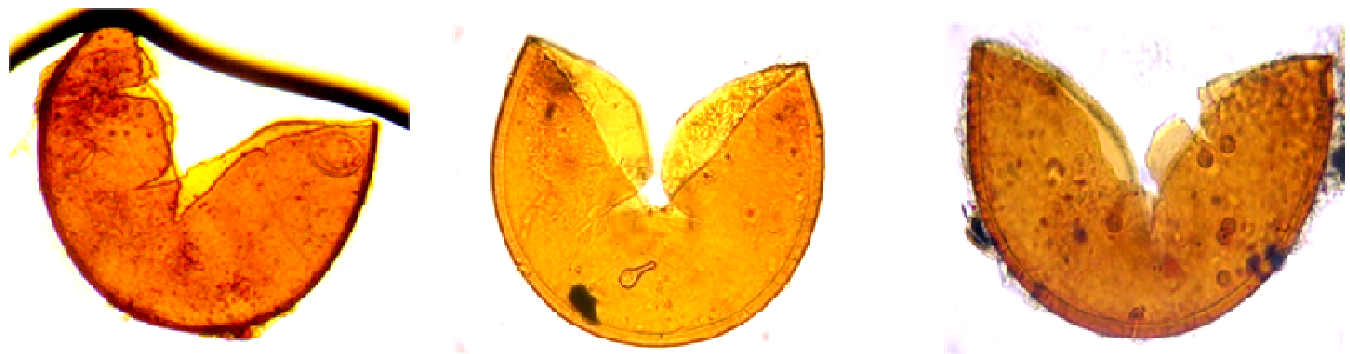

G. grosporim
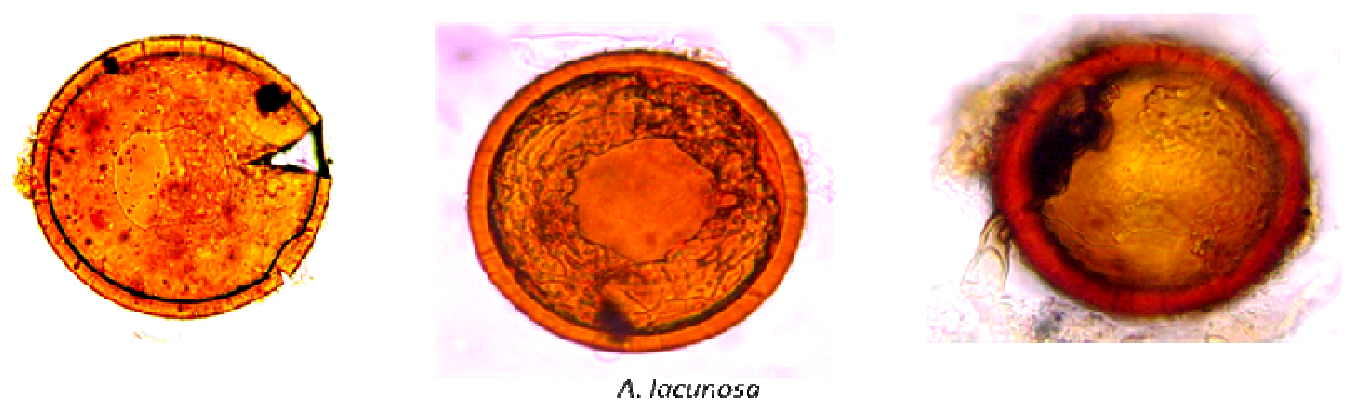

Plate 5. Diversity of AM spores 


\section{Conclusions}

Generally, better nutrient (especially P) and water uptake leads to increase in bamboo biomass. Bamboo species were benefited by VA-mycorrhizal fungi which was evident from this study that all bamboos were infected by endomycorrhizae under natural condition. However, their population and root infection varied considerably among species to species. Bamboo, being a fast growing plant, requires more nutrients during the initial stage of seedling establishment. During this period, the root system is not well developed and the AM fungal symbiosis might play a vital role by supplying the nutrients to the host plant. The results of present study showed that all the target plant species are highly dependent on mycorrhizal associations for its survival, growth and development. Therefore, the inoculation of VA mycorrhizal fungi at the time of plantation may be beneficial as the phosphorus requirement of bamboo can be optimized through AM inoculation.

\section{Acknowledgements}

This work was supported by Indian Council of Forestry Research and Education, Project No.: RFRI/201516/SFM-1. The authors are thankful to The Director, Rain Forest Research Institute (ICFRE) for providing all necessary facilities. We are also thankful to the inhabitants of the Tilikiaam, Maoutgaon and Nathgaon of Jorhat district, Assam, for co-operation and providing the useful information required for the biodiversity exploratory survey.

\section{Conflict of interest}

The author(s) declares that there are no conflicts of interest related to this article.

\section{References}

Allen MF (1992). Mycorrhizal functioning: an integrative plant-fungal process. Chapman and Hall, New York.

Bonfante-Fasolo P (1984). Anatomy and morphology of VA mycorrhizae. VAMycorrhizae 57:5-33.

Caldwell BA, Jumpponen A, Trappe JM (2000). Utilization of major detrital substrates by dark septate, root endophytes. Mycologia 92(2):230-232.

Cho EJ, Lee DJ, Wee CD, Kim HL, Cheong YH, Cho JS, Sohn BK (2009). Effects of AMF inoculation on growth of Panax ginseng C.A. Meyer seedlings and on soil structures in mycorrhizosphere. Scientia Horticulturae 122(4):633-637.

Cruz RED, Husain T (2008). Effect of vesicular arbuscular mycorrhiza (VAM) fungi inoculation on coppicing ability and drought resistance of Senna spectabilis. Pakistan Journal of Botany 40(5):2217-2224.

Currah RS, Tsuneda A (1993).Vegetative and reproductive morphology of Phialocephala fortinii (Hyphomycetes, Mycelium radicis atrovirens) in culture. Transactions of Mycological Society ofJapan 34:345-356.

Das P, Kayang H (2010). Arbuscular mycorrhizal fungi and dark septate endophytes colonization in bamboo from North east India. Frontiers of Agriculture in China 4(3):375-382

Dash D, Naugraiya MN, Gupta SB (2008). Response of three bamboo species to vesicular arbuscular mycorrhiza inoculation in nursery. Range Management and Agroforestry 29(2):125-128.

Fernando AA, Currah RS (1995). Leptodontidium orchidicola (Mycelium radicis atrovirens complex): aspects of its conidiogenesis and ecology. Mycotaxon 54:287-294.

Gaur A, Adholeya A (1994). Estimation of VAMF spores in soil: a modified method. Mycorrhiza News 6(1):10-11.

Gerdemann JW, Nicholson TH (1963). Spores of mycorrhizal Endogene extracted from soil by wet sieving and decanting. Transactions of British Mycological Society 46:235-244.

Gianinazzi - Pearson V, Smith SE, Gianinazzi S, Smith FE (1991). Enzymatic studies on the metabolism of vesicular-arbuscular mycorrhizas: V. Is H+-ATPase a component of ATP-hydrolysing enzyme activities in plant-fungus interfaces? New Phytologist 117(1):61-76.

Govindarajulu M, Pfeffer PE, Jin H, Abubaker J, Douds DD, Allen JW, ... Shachar-Hill Y (2005). Nitrogen transfer in the arbuscular mycorrhizal symbiosis. Nature 435(7043): 819-823.

Hall IR (1988). Potential for exploiting vesicular-arbuscular mycorrhizae in agriculture. Advances in Biotechnological Processes (USA) 2:175-202.

Harley JL, Smith SE (1983). Mycorrhizal symbiosis. Academic Press, London, pp 483.

Harris D, Pacovsky RS, Paul EA (1985). Carbon economy of soybeanrhizobium-glomus associations. New Phytologist 101(3):427440.

Haselwandter K, Read DJ (1980). Fungal associations of roots of dominant and sub-dominant plants in high-alpine vegetation systems with special reference to mycorrhiza. Oecologia 45:57-62.

Hayman DS (1975). The occurrence of mycorrhiza in crops as affected by soil fertility. In: Sanders FE, Mosse B, Tinker PB (Eds). Endomycorrhizas. Academic Press, London pp 495-509.

Hock B, Varma A (1995). Mycorrhizastructure, function, molecular biology and biotechnology.Springer, Berlin.

Jamaluddin A, Chandra KK, Goswami MJ (2001). Effectiveness of various types of VAM inocula on growth and biomass of Bambusa nutans. Mycorrhiza News 12(3):15-17.

JhaA, Kumar A,Saxena RK, KamalvanshiM, ChakravartyN (2012).Effect of arbuscular mycorrhizal inoculations on seedling growth and biomass productivity of two bamboo species. Indian Journal of Microbiology 52(2):281-285.

Jha DK, Sharma GD, Mishra RR (1992). Ecology of soil microflora and mycorrhizal symbionts in degraded forests at two altitudes. Biology and Fertility of Soils 12(4):272-278.

Jiang W, Gou G, Ding Y (2013). Influences of arbuscular mycorrhizal fungi on growth and mineral element absorption of Chenglu hybrid bamboo seedlings. Pakistan Journal of Botany 45(1):303-310.

Johansson JF, Paul LR, Finlay RD (2004). Microbial interactions in the mycorrhizosphere and their significance for sustainable agriculture. FEMS Microbiology Ecology 48(1):1-13.

Jumpponen A (2001). Dark septate endophytes - are they mycorrhizal? Mycorrhiza 11(4):207-211. 
454

Jumpponen A, Mattson K, Trappe JM (1998). Mycorrhizal functioning of Phialocephala fortinii with Pinus contorta on glacier fore front soil: interactions with soil nitrogen and organic matter. Mycorrhiza $7(5): 261-265$.

Jumpponen A, Trappe JM (1998). Dark septate endophytes: a review of facultative biotrophic root colonizing fungi. The New Phytologist 140(2):295-310.

Khan SN, Uniyal K (1999). Association of arbuscular mycorrhizal fungi with different bamboo species at a reforested site. Indian Journal Forestry 22:405-408.

Liu RJ, XL Li (2000). Arbuscular mycorrhizae and its application. Science Press, Beijing, pp 70-71.

Martin JK (1971). Influence of plant species and plant age on rhizosphere microflora. Australian Journal of Biological Sciences 24(4):1143-1150.

Miller RM (1979). Some occurrence of vesicular-arbuscular mycorrhiza in natural and disturbed ecosystems of the red desert. Canadian Journal of Botany 57(6):619-623.

Morton JB, Benny GL (1990). Revised classification of arbuscular mycorrhizal fungi (Zygomycetes): New order, Glomales two new suborders Glomineae and Gigasporineae and two new families, Aculosporaceae and Gigasporaceae with emendation of Glomaceae. Mycotaxon 37:471-491.

Mukerji KG (1996). Taxonomy of endomycorrhizal fungi. In: Mukerji KG, Mathur B, Chamola BP, Chitralekha P (Eds). Advances in Botany, APHPub.Crop. New Delhipp211-221.

Nemec S, Guy G (1982). Carbohydrate status of mycorrhizal and nonmycorrhizal citrus root stocks. Journal American Society for Horticultural Science 107:177-180.
Nemec S, Meredith FI (1981). Amino acid content of leaves in mycorrhizal and non-mycorrhizal citrus root stocks. Annals of Botany 47(3):351358.

Phillips JM, Hayman DS (1970). Improved produces for clearing roots and staining parasitic and VAM fungi for rapid assessment of infection. Transactions of the British mycological Society 55(1):158-161.

Ravikumar R, Anathakrishnan G, Appasamy T, Ganapathi A (1997). Effect of endomycorrhizae (VAM) on bamboo seedling growth and biomass productivity. Forest Ecology and Management 98(3):205-208.

Rillig MC (2004). Arbuscular mycorrhizae, glomalin, and soil aggregation. Canadian Journal ofSoil Science 84(4):355-363.

Rillig MC, Mummey DL (2006). Mycorrhizas and soil structure. New Phytologist 171(1):41-53.

Schenck NC, Perez Y (1990). Manual for the identification of VA mycorrhizal (VAM) fungi. University of Florida, Synergistic Pub., Florida, USA, pp 241.

Serrigny J (1982). Etudes cytologiaue, cytochimique, et cytoenzyrnologique dune orchidee tropicale: Epidendrum sp. Diplomed Etude Approfondie, University of Nancy,pp 32.

Simard SW, Jones MD, Durall DM (2002). Carbon and nutrient fluxes within and between mycorrhizal plants. In: Van der Heijden MGA, Sanders IR (Eds.). Mycorrhizal ecology. Springer-Verlag, Berlin pp 3374.

Singh S (2001). Mycorrhizal dependency, Part 3: evaluation of dependency and intraspecific variation. Mycorrhiza News 13(3):2-12.

Smith FA (1996). Mutualism and parasitism: diversity in function and structure in the 'arbuscular' (VA) mycorrhizal symbiosis. Advances in Botanical Research 22:1-43. 